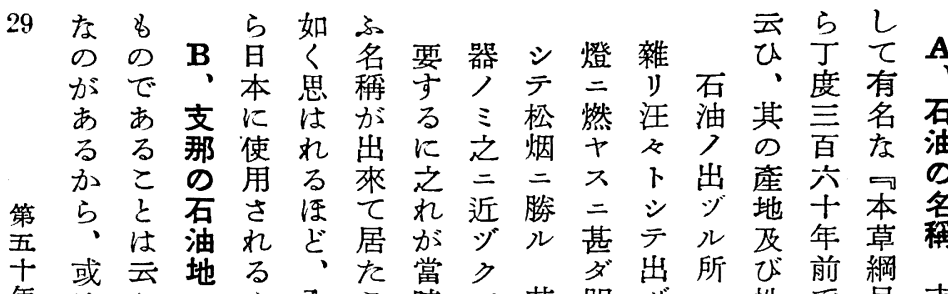

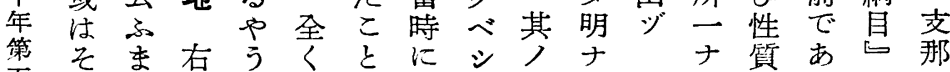

吾机でのに同は於油》肥ラにる位は

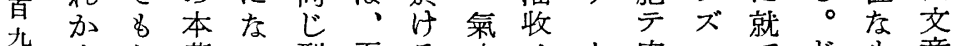

十\&草つ型吾る味メ水肉婪に゙を章

五知い綱たで人石辛難

號れが目艻あに油苦シ得, 西次なで國

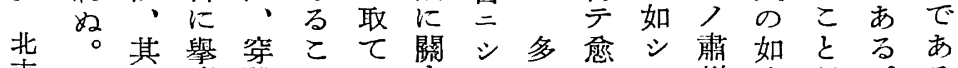

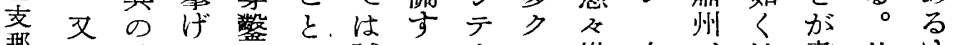
た他て造誠る毒八傤土! 逊書此的

石䋶のあて、㵊有器ナ人延心いのれ

油甸\&方見頗面上リ物り草長てて書を゙

情あに油ば興い智云滃食以鄜るるの

る至產面味こ識穴飿三テ州。加刊石

の圭地白深と无不把! 行油

ははのいいであいル雲自さに

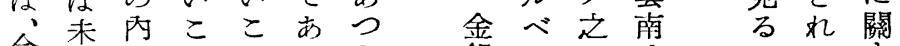

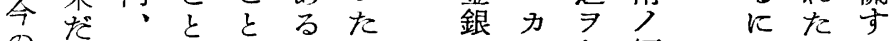

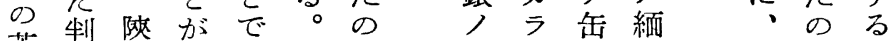

英明西發あ更で器ズ中甸先は齐

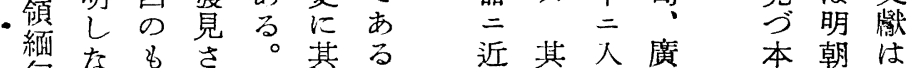

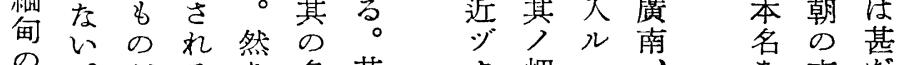

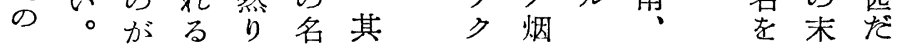

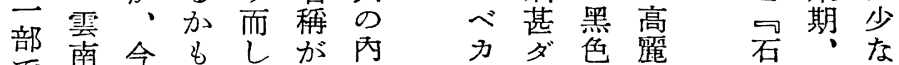

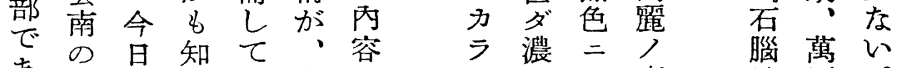

あ廣、知此英の容浱二東油曆。

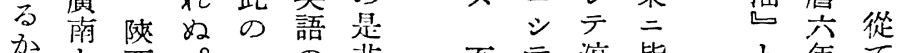

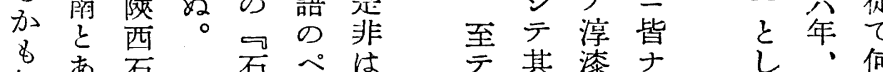

知京石 石

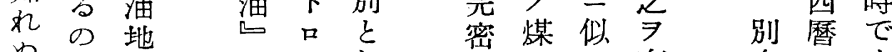

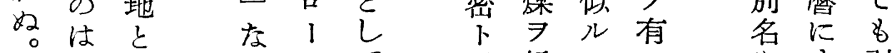

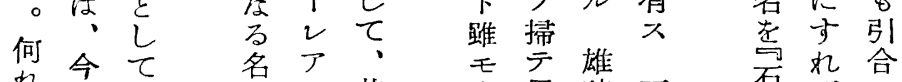

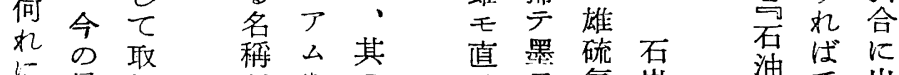

に昆报染を学氣岩油千出

乙明は、翻當二作妇手五さ

四当柷何譯時透ル作少石百れ

三佔南て 時しに渦ル流漆七る

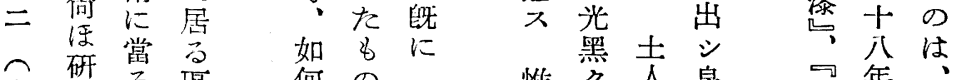

志研究區何の品惟学食泉雄年

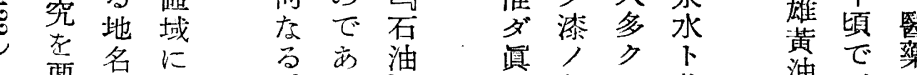

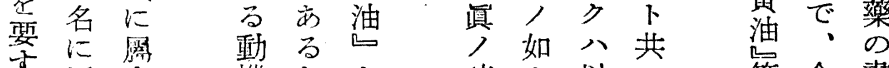

總

北

支

那

の

說

石

油

事

情

理。

學

$\pm$

大

村

藏

等 今 踷 
にし獨にとうう使謂面のの同であめし併 30

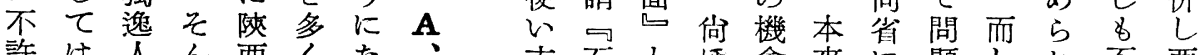
許は人ん西く故方石上注會來に題しれ不西

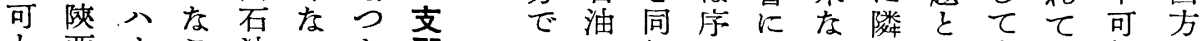
と西ネこ油つた那亦のしに讓ら接な本居能怯

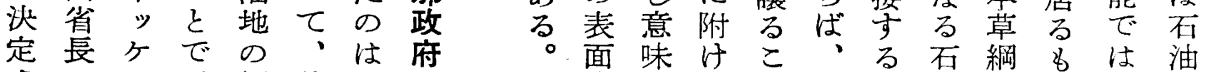

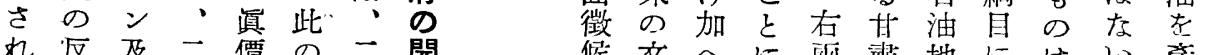

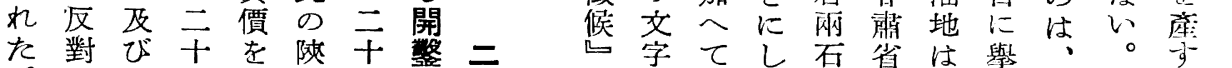

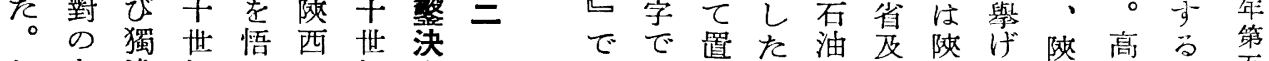

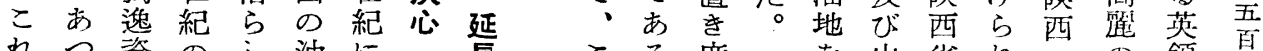

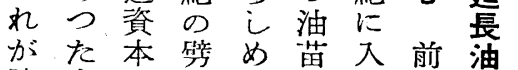
敶上の頭るにつ迅田 西に世: 動目ての開 石、昌郎機をか中拓

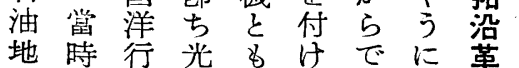
に、と緒なるあ、 對交協等艺者る傸 し 那同十た が。西 $\tau$ 國 L 七 の 多其省 外民て 年でくの内 國間?而あな動の 凟㳊延西るつ機油 本昂長曆。たと苗 家揚縣二代云存 の

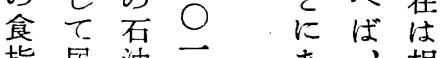
指居油年あ相 をつ開年る十當 動た掘にの九古 分排權至で世く

し外をる あ紀か

た感獲て 最情得山 初 \& の手べ省

事 傳く劣 件支理 でて那縣 あ、政の る。杰 そ頃那 ᄂ 加人 $\tau$ 万 る光府手でら こ緒に落支れ れ立向㓺濭內那居 に九てび と地た 次年運傸云のが で西動西交旅 光西省省始延行企

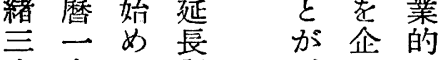

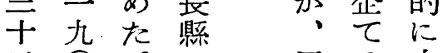
年兰併劉 對字老 に年し德江の取 、管支报 含に遂對は、那段ふ

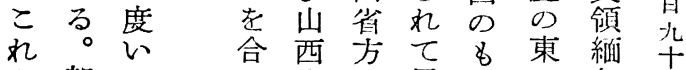
を郎こ某省面居の云甸吾 以ちを、てのと祐 て石は紹一四いけに接 油油: 介部川場占至し

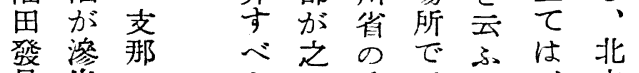

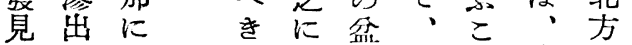
のしはで加地確を全は 手て市は區貫にく多事 掛居油るつ域と見少情 とた画がて茷認る當で

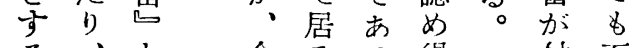
る、 $\varepsilon$ 今 る得付石 の水云回ののる少油 でなふはでで石はな゙ あど文北ああ油發 ると学荠るる發筧 か一の那。見こさ ら所あに但地儿れ

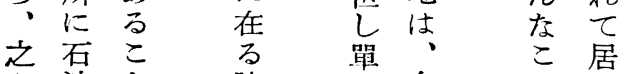

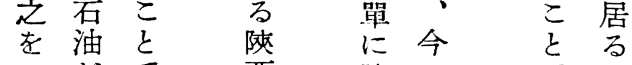
分で西煺の元

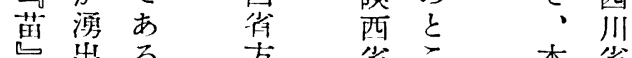
と出る。方省こ本少

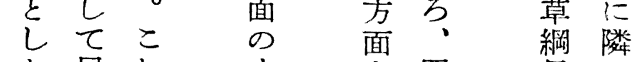
た居れ多点四目る のたは云川關

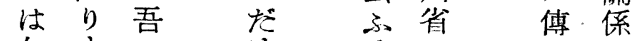

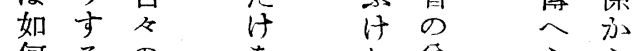

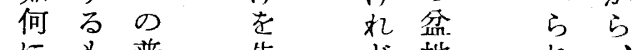
に普先占地れ、

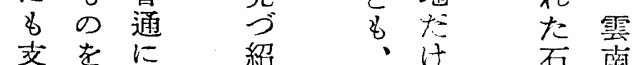
那云用介其で油省

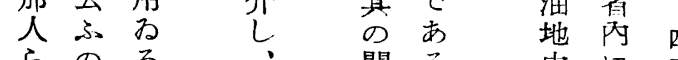

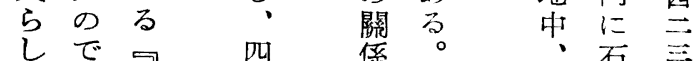
しだ油四傃從合石

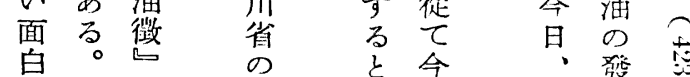

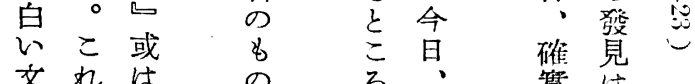

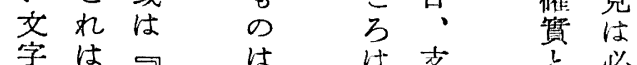

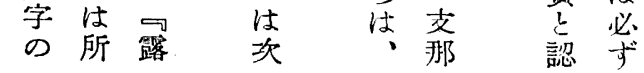

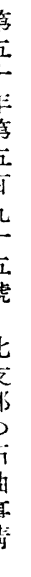




\begin{tabular}{|c|c|c|c|c|c|c|c|c|c|c|c|c|c|c|c|c|c|c|c|c|c|}
\hline 31 & & & の & & & 樣 & & は & 街 & $\sigma$ & 此 & た & 望 & K & 時 & & & 西 & & & \\
\hline & ১ & C & で & $こ$ & 此 & で & 百 & 少 & の & に & の & & で & は & & B & 以 & & 加 & & \\
\hline & 間 & & & h & の & あ & 五 & な & 西 & 對 & $\vec{z}$ & 依 & あ & 最 & 武 & & 上 & 廳 & $<$ & 功 & 蘭閏 \\
\hline & 獨 & 弟 & 䈉 & $\begin{array}{l}\sqrt{5} \\
\text { 狀 }\end{array}$ & 成 & t & 尺 & $\begin{array}{l}\text { s } \\
5\end{array}$ & $\begin{array}{l}x_{\beta} \\
k\end{array}$ & $\frac{\tau}{\tau}$ & 行 & 洪 & $\begin{array}{l}2 \\
\varepsilon\end{array}$ & 適 & $\begin{array}{l}\text { 學 } \\
\text { 严 }\end{array}$ & $\begin{array}{l}\text { 日 } \\
\text { 本 }\end{array}$ & ? & 其 & $\begin{array}{l}\text { 怕 } \\
\text { 次 }\end{array}$ & 㖉 & \\
\hline & 逸 & 次 & 治 & 態 & $k$ & מ & で & ず & 位 & 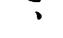 & び & 知 & の & 當 & 堂 & i & 陝 & の & ぐ & & \\
\hline & 人 & 日 & 四 & で & 基 & 5 & 掘 & 手 & 置 & 黃 & 機 & 事 & 結 & L & の & の & 西 & 事 & 外 & L & \\
\hline & は & 本 & + & 延 & $\checkmark$ & & 進 & 間 & を & \pm & 峨 & は & 論 & た & 攵 & 技 & 石 & 業 & 人 & め & \\
\hline & 資 & 技 & 一 & 長 & $\tau$ & 關 & を & 取 & 選 & の & 器 & 稻 & を & 人 & 授 & 師 & 油 & を & の & 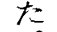 & \\
\hline & 金 & 師 & 年 & 狀 & 小 & 係 & 中 & כ & み & 道 & 具 & 並 & 得 & で & で & の & 地 & 遂 & 權 & & \\
\hline & 貸 & 招 & 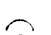 & の & 製 & 者 & 止 & た & • & は & は & 氏 & $\tau$ & あ & あ & 活 & の & 行 & 利 & & \\
\hline & 付 & 聘 & 光 & 石 & 所 & は & L & & 警 & 柔 & 明 & 壳 & 布 & 3 & 3 & 躍 & 試 & せ & 獲 & & \\
\hline & 备 & & 緒 & 油 & が & 大 & & z & 井 & 兮 & 治 & 介 & 政 & た & た & & 招 & 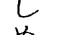 & 得 & & \\
\hline & 同 & 早 & 三 & 8 & 建 & に & 油 & れ & に & $<$ & $\equiv$ & & 更 & & & מ & $z$ & $\infty$ & 尰 & & \\
\hline & 時 & 本 & 千 & 幸 & 設 & 䔨欠 & 量 & で & 着 & $\tau$ & + & $\tau$ & K & 氏 & 昜 & $<$ & 受 & る & 動 & & \\
\hline & 銅 & 人 & 年 & 先 & c & 豆 & 旁 & 8 & 手 & 量 & 元 & 日 & ह & 12 & t: & c & 3 & ${ }_{L}^{C}$ & & & \\
\hline & 凅 & 揚 & $\underset{\cup}{*}$ & 甚 & t & t & 算 & 共 & た & 機 & 垖 & 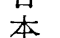 & 兄 & 析 & Tre & 政 & $k$ & $に$ & & & \\
\hline & 獲 & 後 & - & だ & 10 & & L & 年 & の & 械 & $\hbar$ & 加 & た & の & 莘 & 使 & 至 & L & & & \\
\hline & 得 & は & 月 & 善 & 之 & & $\tau$ & 毁 & は & を & 光 & 5 & & 結 & 吉 & は & 工 & た & 政 & & \\
\hline & の & & & מ & れ & & 見 & 5 & 同 & 運 & 緒 & 蔹 & 於 & 果 & 氏 & & $\hbar$ & & 付 & & \\
\hline & 目 & 港 & 日 & $?$ & が & & た & 光 & 年 & Ss & 三 & 茾 & 此 & & で & 先 & 抑 & 其 & む & & \\
\hline & 的 & 黃 & 本 & た & 今े & & 5 & 緒 & の & に & 十 & 機 & & 良 & あ & $\breve{~}$ & 及 & • の & 束 & & \\
\hline & で & の & 人 & の & 8 & & ば & $\equiv$ & 四 & 適 & 二 & 亚 & 布 & 好 & 3 & 油 & の & 結 & 3 & & \\
\hline & 西 & 監 & 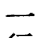 & で & 在 & & 日 & 土 & 月 & L & 年 & に & 政 & な & た & 苗 & 動 & 果 & に & & \\
\hline & 安 & 督 & 行 & あ & る & & 產 & $\equiv$ & で & な & 分 & 精 & 使 & 石 & & に & 機 & 陝 & & & \\
\hline & に & の & は & る & 製 & & 六 & 年 & あ & い & 月 & 油 & は & 油 & 稻 & 溜 & で & 西 & & & \\
\hline & 秉 & 1 & 全 & け & 油 & & 干 & 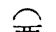 & 3 & か & & 裝 & 洪 & で & E & る & あ & 省 & & & \\
\hline & 運 & 少 & 部 & れ & 所 & & 政 & 盲 & To & 5 & 漢 & 直 & 黄 & あ & 氐 & 石 & る & で & 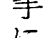 & & \\
\hline & 動 & L & 麻 & 8 & あ & & あ & 百 & 而 & 千 & に & 守 & 延 & 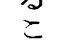 & 明 & を & & は & 依 & & \\
\hline & & < & さ & & & & 工 & 九 & L & 辛 & 到 & 購 & 長 & $\varepsilon$ & 治 & 武 & & & & & \\
\hline & た & 熟 & れ & 樊 & & & た & 0 & $\tau$ & 萬 & 達 & 入 & 縣 & を & 兰 & 昌 & & & 開 & & \\
\hline & か & 練 & $\tau$ & 布 & & & & 七 & 機 & 苦 & L & के & 知 & 知 & & & & 梦 & 警 & & \\
\hline & & L & 此 & 政 & & & 之 & 年 & 械 & の & た & 3 & 事 & ?. & 西 & & & 增 & 9 & & \\
\hline & 父 & た & ১ & 使 & & & $\frac{x}{+}$ & & 03 & 杰 & of & と & & & & & & 神 & b & & \\
\hline & 少 & 被 & 地 & の & & & 其 & ब & 破 & 7 & れ。 & 同 & 㶵 & 更 & & & & $\ddot{z}$ & 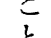 & & \\
\hline & L & 職 & 引 & 耻 & & & + & 月 & & 䒨 & 4 & $m$ & 5 & r- & 栐 & 析 & & & の & & \\
\hline & な & I. & き & & & & 地 & に & 或 & の & & & 省 & 陌 & & & & & & & \\
\hline & か & を & 拂 & 曹 & & & で & は & は & 一 & 河 & 越 & 金 & の & 大 & 行 & & & & & \\
\hline & 3 & 使 & 3 & 巡 & & & & 深 & 日 & 月 & 南 & 後 & $E$ & 調 & & 1 & & & & & \\
\hline & た & 役 & た & 檢 & & & 時 & 度 & 本 & K & 省 & מ & 萬 & 査 & 學 & L & & 之 & あ & & \\
\hline & p & L & の & の & & & 價 & 三 & よ & 漸 & 谷 & 5 & 兩 & 榢 & 科 & た & & の & & & \\
\hline & j & $\tau$ & で & 交 & & & に & 百 & り) & & 州 & 技 & & を & 出 & & & 事 & 0 & & \\
\hline & な & , & あ & 迭 & & & $\underline{L}$ & $\equiv$ & の & 目 & 以 & 師 & 芰 & 派 & 身 & 此 & & 業 & & & \\
\hline & 事 & わ) & る & 等 & & & $\tau$ & 十 & 部 & 的 & 西 & & 出 & 遣 & で & & & & 心 & & \\
\hline & 件 & 5 & & が & & & 見 & 尺 & 分 & 地 & は & 名 & L & L & あ & 時 & & 營 & 付 & & \\
\hline & 8 & מ & & あ & & & $れ$ & で & 品 & に & 馬 & & & $\tau$ & D & & & & き & & \\
\hline & あ & に & & 3 & & & ば & 石 & の & 到 & 車 & 職 & 石 & 筫 & た & 其 & & 當 & & & \\
\hline & 3 & 探 & & $\tau$ & & & 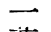 & 油 & 未 & 着 & に & I & 油 & 也 & か & & & & 曹 & & \\
\hline & たc & 油 & & 雀 & & & 禹 & 愿 & 到 & L & 依 & 穾 & 咸 & 調 & 5 & 分 & & L & 巡 & & \\
\hline & & を & & の & & & 七 & に & 着 & た & 5 & 名 & 創 & 查 & L & 析 & & め & 檢 & & \\
\hline & & 稿 & & 万 & & & 千 & 逢 & 等 & & な & 亮 & 設 & 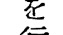 & $\tau$ & に & & る & に & & \\
\hline & & it & & 針 & & & 兩 & 着 & の & そ & H & 雇 & & 行 & & & & & 訓 & & \\
\hline & & $\tau$ & & が & & & に & L & た & $\underline{L}$ & れ & a & 事 & は & 石 & 3 & & $=$ & 令 & & \\
\hline & & 居 & & $\vec{x}$ & & & 8 & た & $\infty$ & $\tau$ & ば & 入 & に & & 油 & た & & & & & \\
\hline & & 3 & & 櫵 & & & 當 & מ & に & 延 & な & れ & 當 & め & の & 人 & & L & $\tau$ & & \\
\hline & & た & & L & & & 盯 & 5 & $\begin{array}{l}\text { 掘 } \\
\text { 淮 }\end{array}$ & 長 & 5 & た & 5 & & 分 & 黨 & & to & 陆 & & \\
\hline & & & & & & & & & & 市 & 2 & & & 有 & 析 & 當 & & & 挞 & & \\
\hline
\end{tabular}




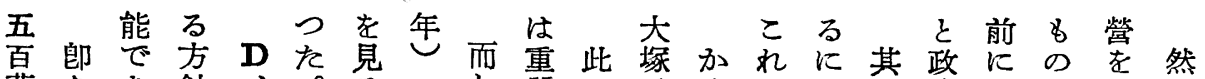

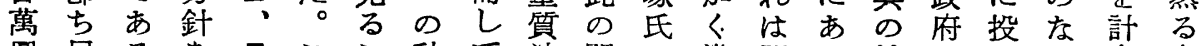
圆民るを的ここ秋て油間二隻明る結に华り企處 の國と固本れと其のに行備治と果傳さ、正に

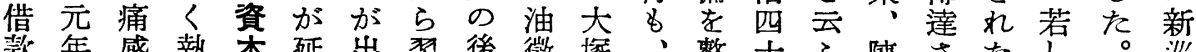

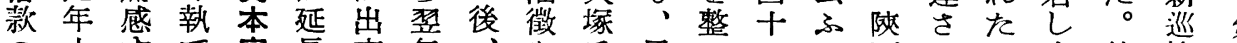

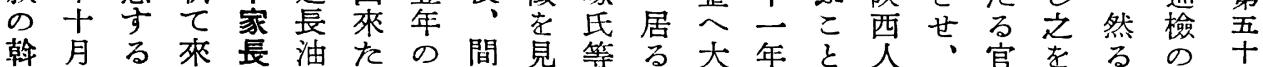

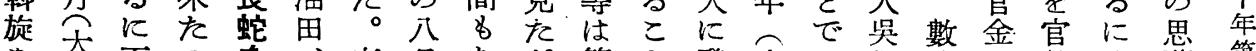

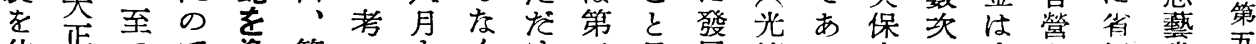

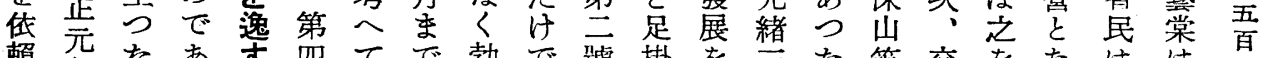

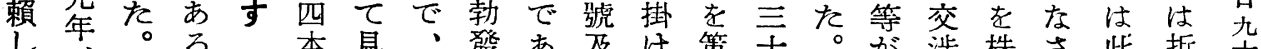

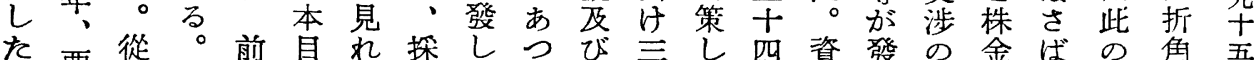

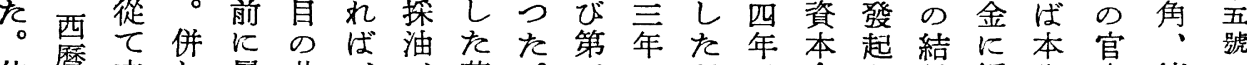

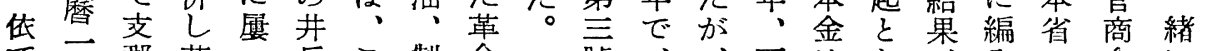

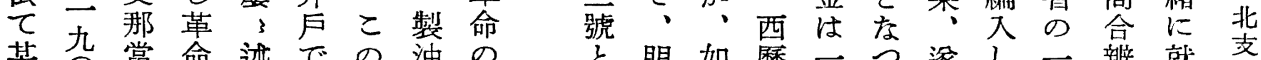

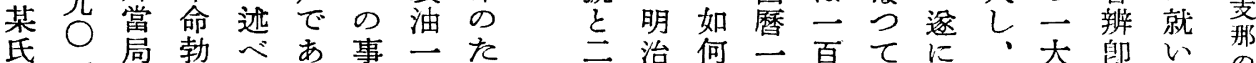

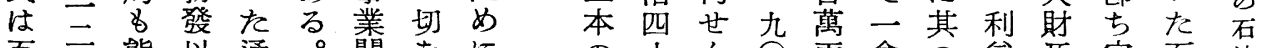
百年態以通。開をにの十ん两會の益源官石油 方莳度來り、始休、油四資八で社目を爷它油事

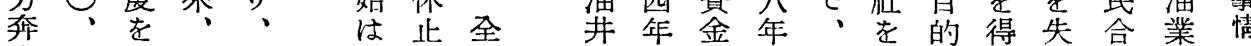

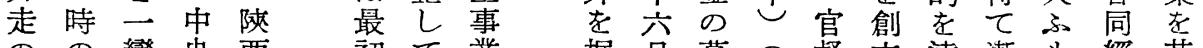

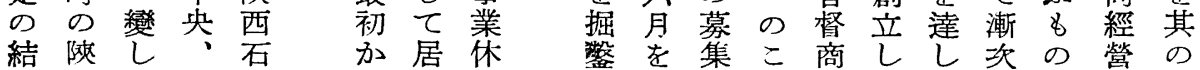

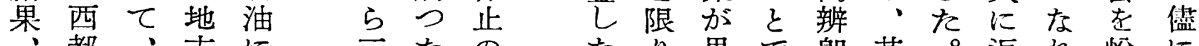
、都、方に言たのの思で郎其。返れ悅に

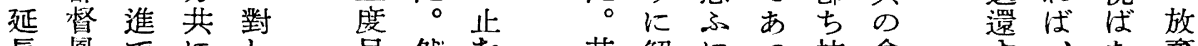
長鳳でにし自然む其解につ技會守小度

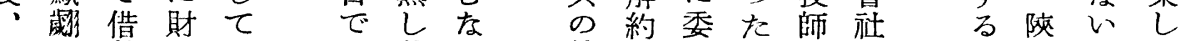
延は款政は专其第しせ等長を方西でて

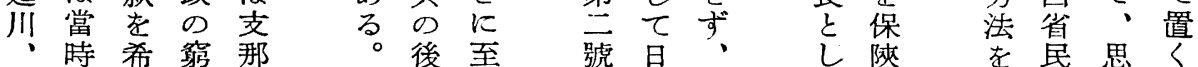

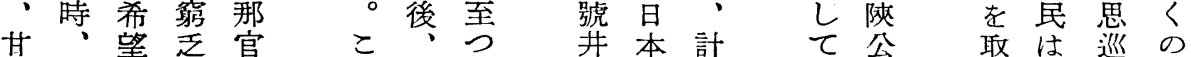

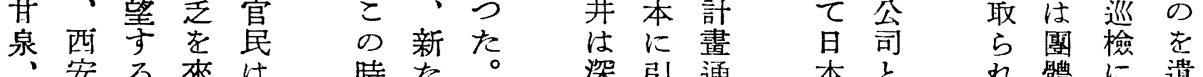
安る來は時た。深引通本と娟に遗

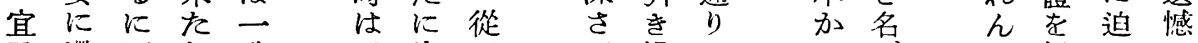

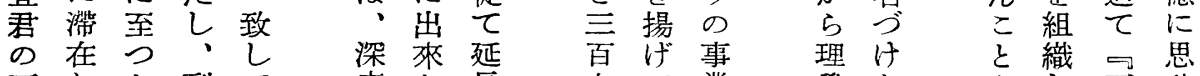
石した到て 度た長 七て業學た。をし 石ひ

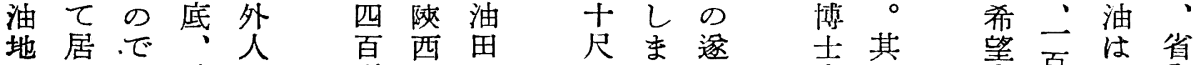

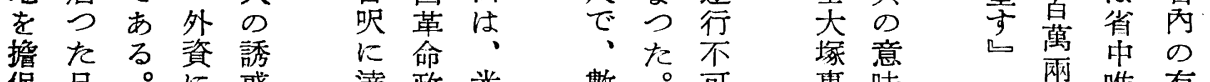
保日。惑達政光數。可專味爾唯有

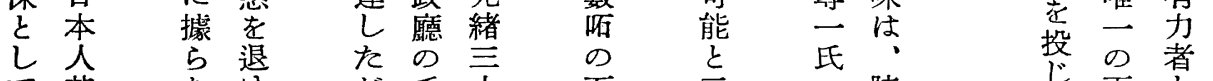

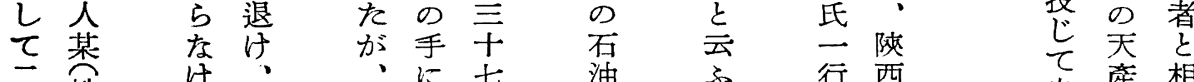

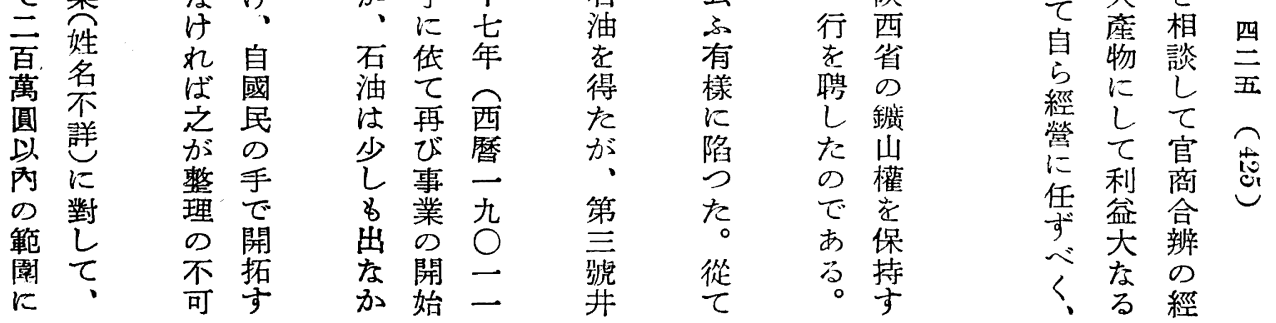




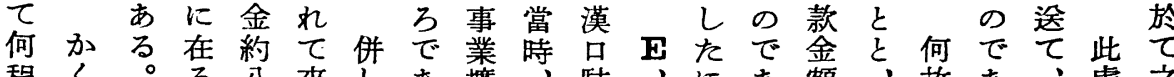

程く○る八來しあ振、䑕、にあ額、故ああ!處之

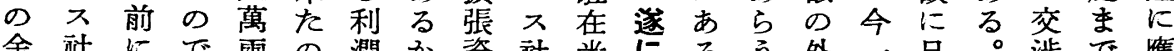

金䫓に

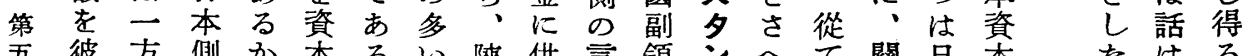

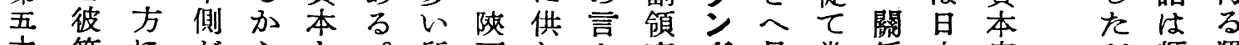

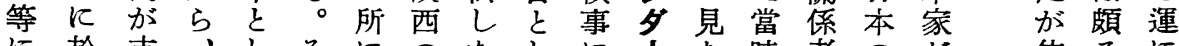

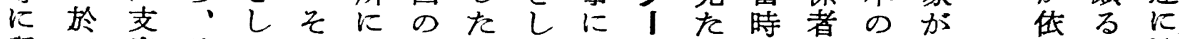

與て出彼てれは人殘て隨ト程、に財か 然順達

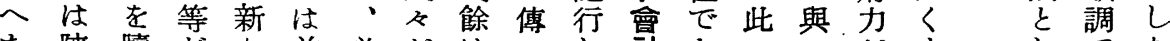

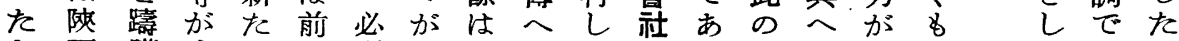

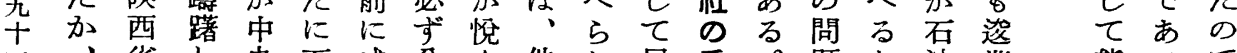

五、省し央石成分ん他れ居手。題た油巡態つで

號表民た政油立けだのたつに併をめ如し た

面をと府倣し前ス有こた歸し翰にきた们け張

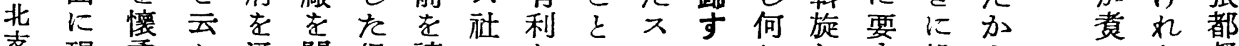

現柔ふ通開保請になは狄は专投と督

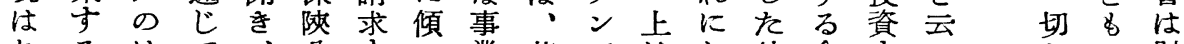

れるはて、公高い業若名迅し 外金票 䒘方、財

て二、買革司るたに公に た のて務額る代、ず愈政

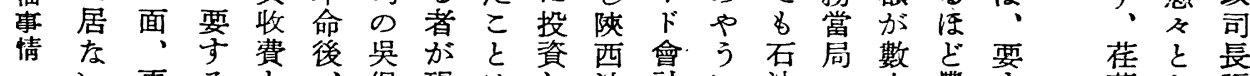

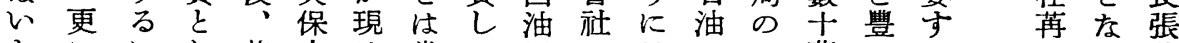

かににし革山は當て田の旦に一萬でる

ら中こて 命二れ然もを二支對人圆なにてて䛦

分央ん三政派るで善米社借すはに方石送見を

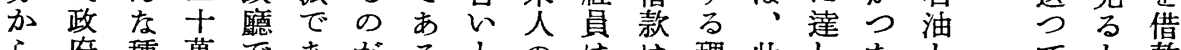

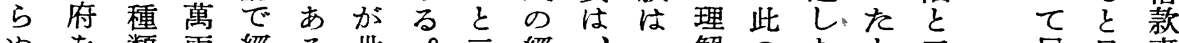

か 黄 類 爾 經る

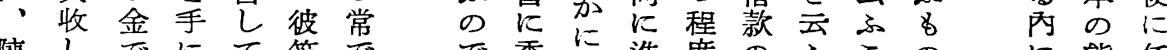

陝しでにて等でで委に傸蕉度の劣このの態任

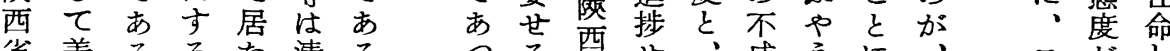

省美るるた清るつる西せ官成うに斿し

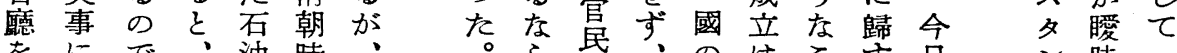

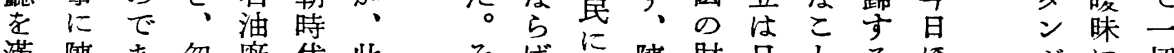

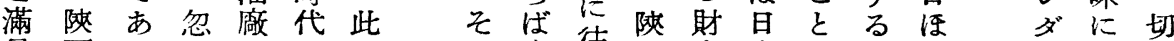

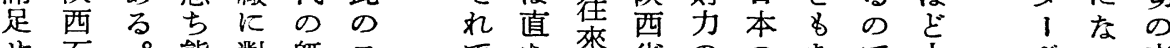

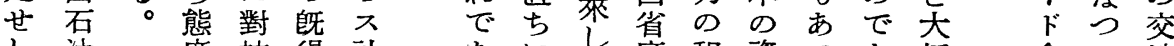

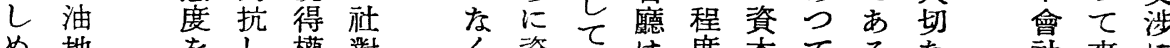

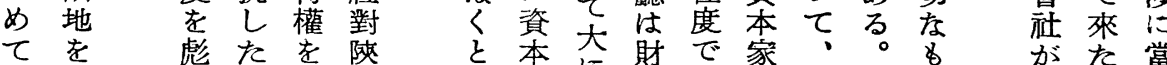

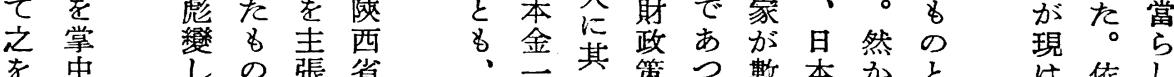

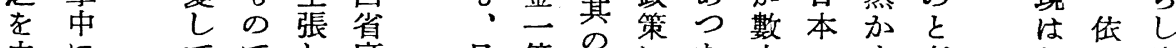

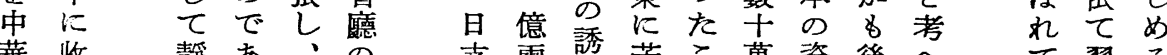

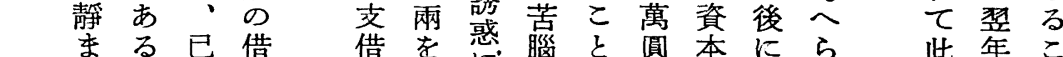

國てる巳借借を䀜腦と圆本にら 此年こ

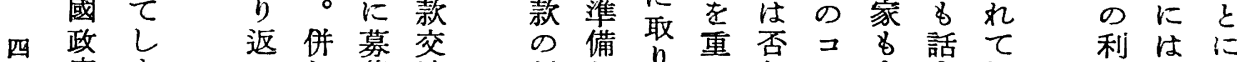

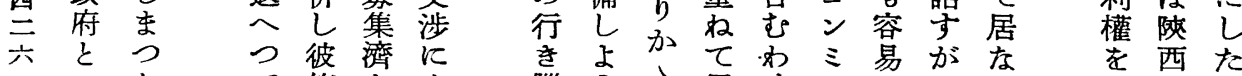

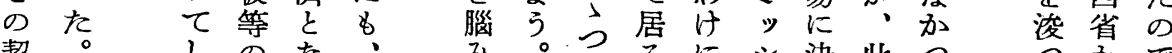

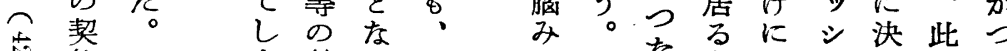

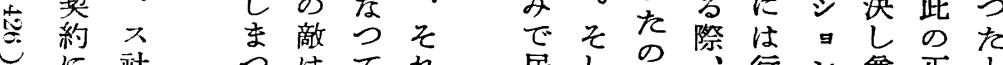

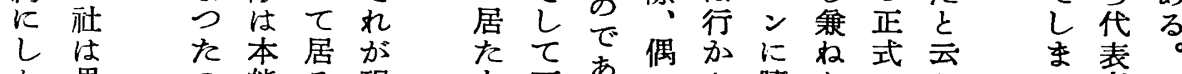

しはは た た本居が 


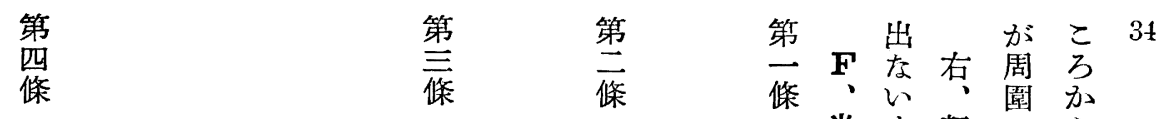

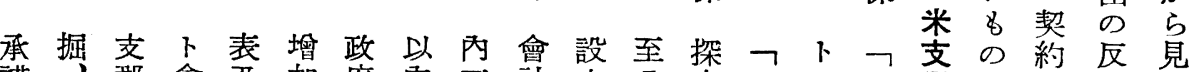

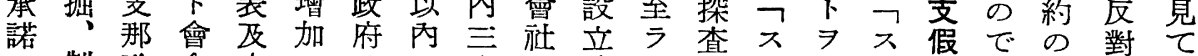

製政合芰ス

具煉府了那儿持原声株六支了ン認ン約る印押、五

㤂八上政場株價牛式ヶ那後がシが全かはし陝十

米貶

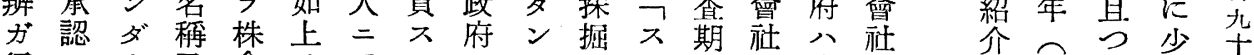

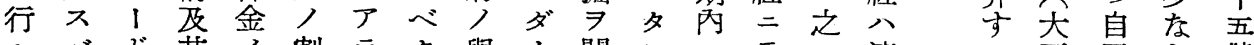

へべド其ノ割ラク與、開ンニテ蔐る正㞯か號

ルシレフ多合ザ若へド始ダア負要當こ主退ら

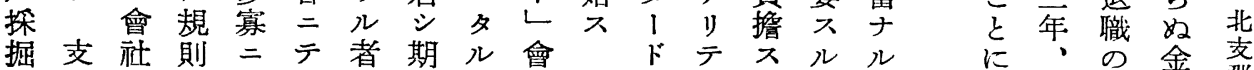

ガ那二章按按二限特社Lモ護委し西間萎删

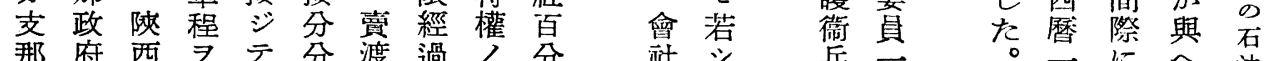

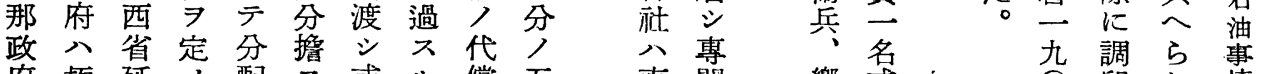

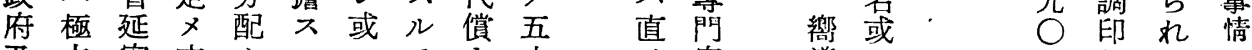

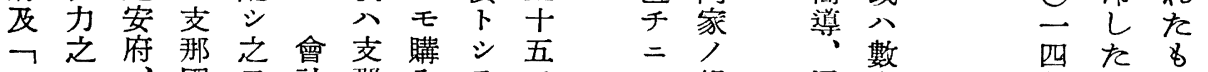

ス二、國 7 社 那入

夕補延民組八人七會支ノ告譯名

ン助長公織完八ザ社那米二更傸

ダ亚縣市ス全所ルョ政等シ 保西

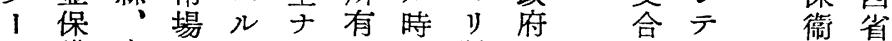

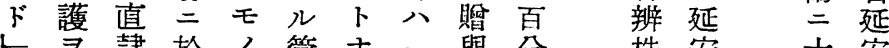

ᄂ $\Rightarrow$ 隷於ノ管ナつ與分株安十安

會加省

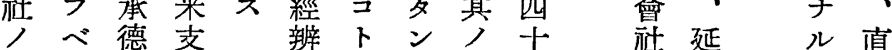

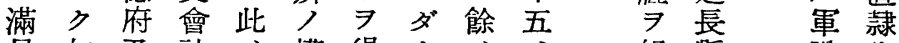

足如及社, 權得、父組縣、陑省

何其入契公ズド七割織或斗承

得ナノ株約董参合济公派德

ザル附券調事將會八三米承遺府

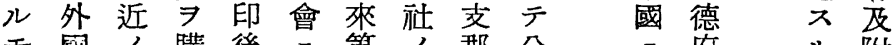

モ圆, 購後三第分那分二府附

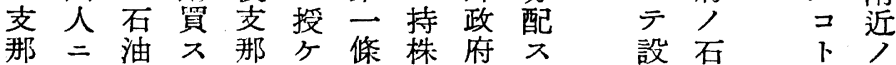

政モ地へ代該二卡二ル 立油 $\quad$ 石

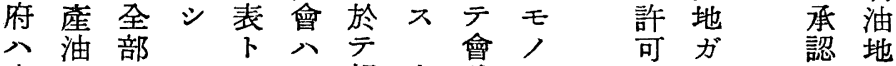

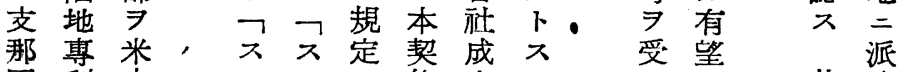

國利支夕夕約立多等其遗

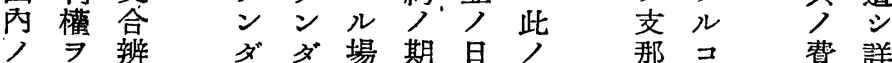

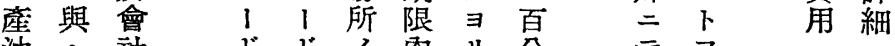

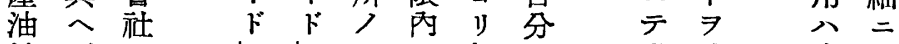

地ザ二玌公起, 登證支探

～ル交會會 $x$ 其算四錄明那查

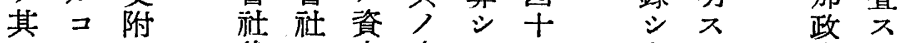

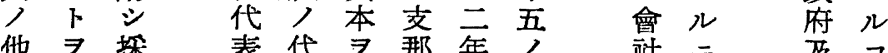

梦で

二 ぞあ

月学ら

あるこ

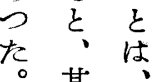

此 其 想

の 間 像

契 のに

的 消 難

の 息く

全想李

は想い。

聊乙又

分得中

長 の政

でで府

ああ

尔者於

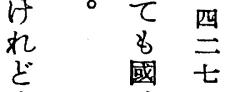

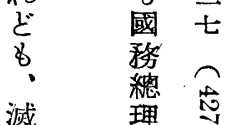

減理 态

に 熊

世希 


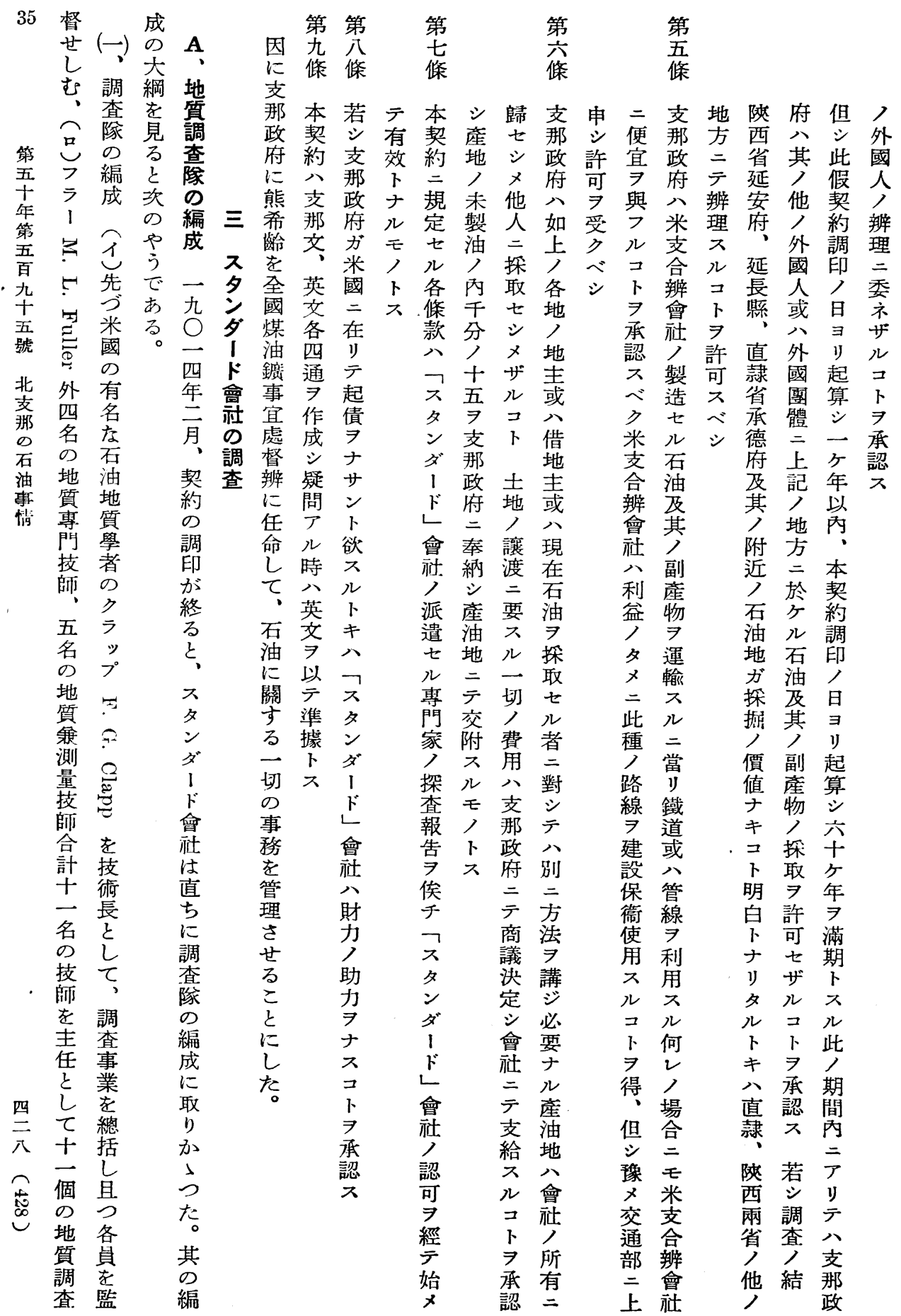




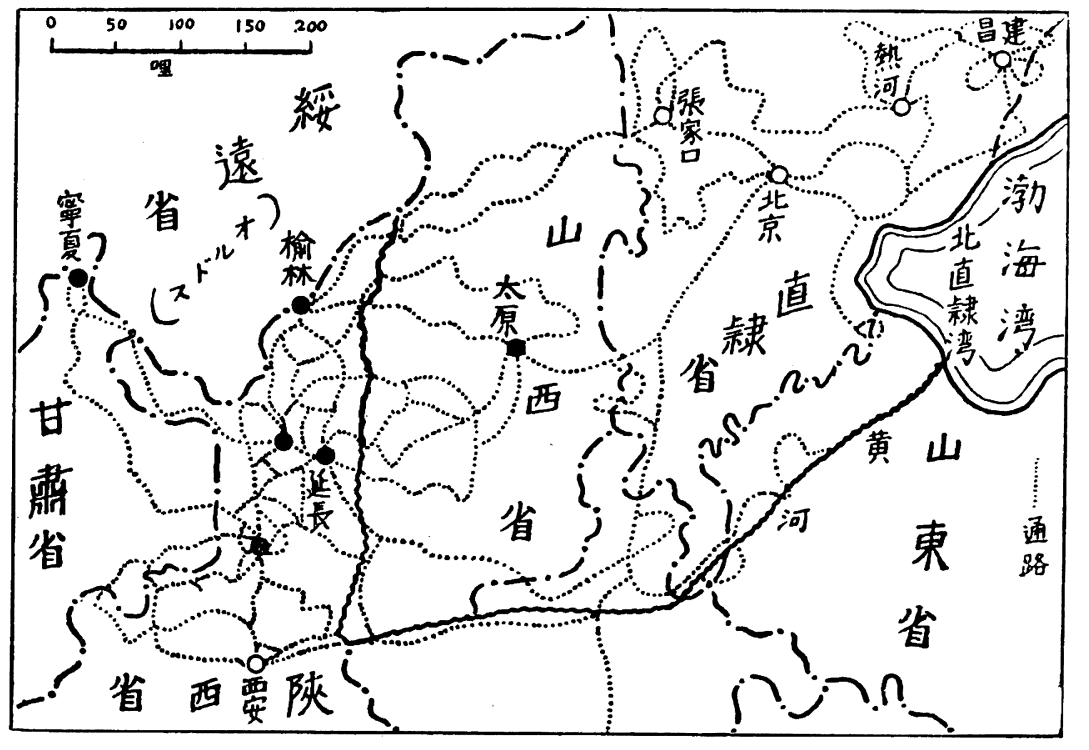

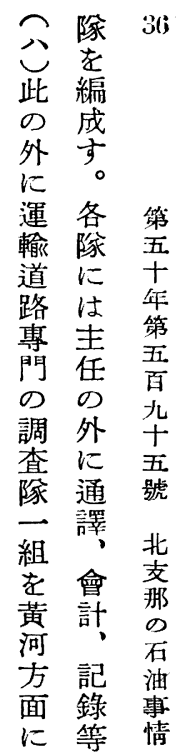

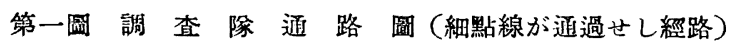

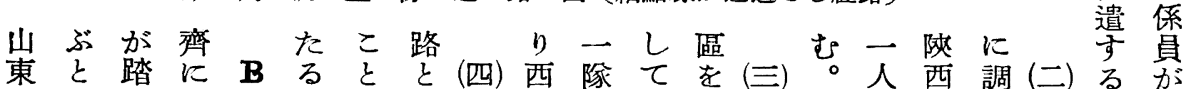

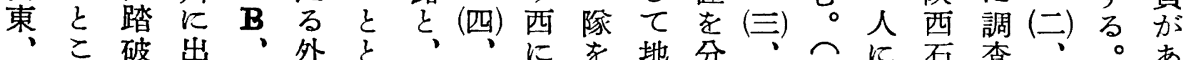
何ろし發調は世油運向太質据地公各油查地刃 る 南は告查、り。田輸ひ原技し形直二地傸質製、

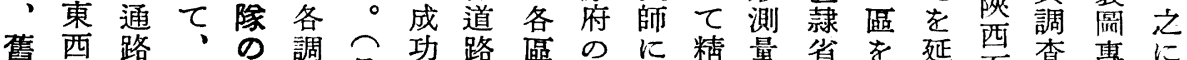
直八で驾活查口の紫を鐵供密量省を延石查專に 肈百あ年躍技右場調通道給古方思分長油方留給 及哩るの師の合查過終守る針に擔延地針を化

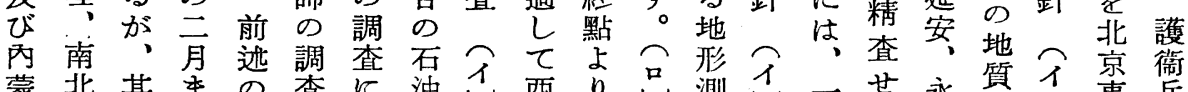

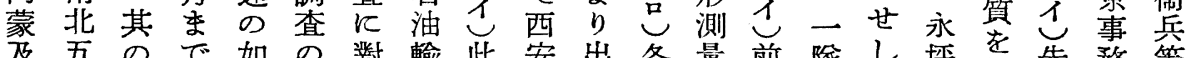
及五ので如の對輸此安出各量前豚し坪を先務等

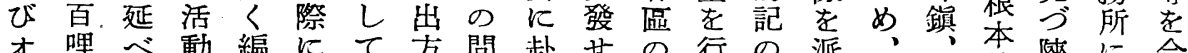
オ哩 ゙動編にて方問赴せの行の派、、本傸に合 ルの哩を成萧は法題吕し高ひ陝遣更店的西置

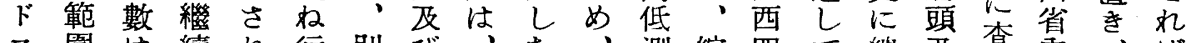

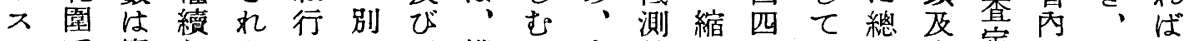
ので貫したはに通機。。高量尺區調地宜定の各少 部少を調し調路械低を域查質君る み䒝な

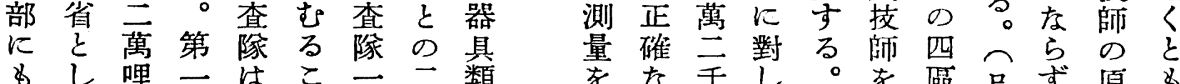

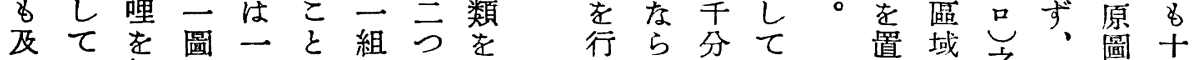

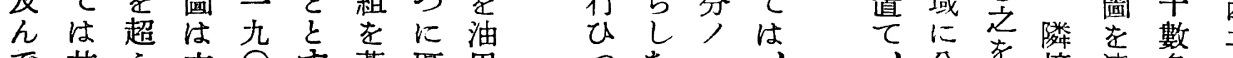

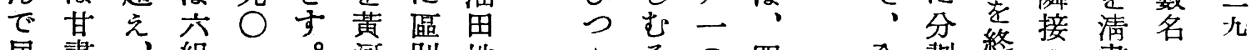

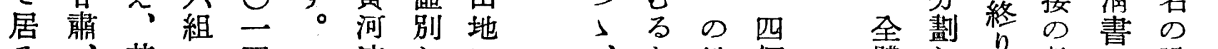

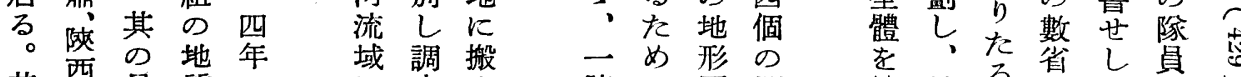

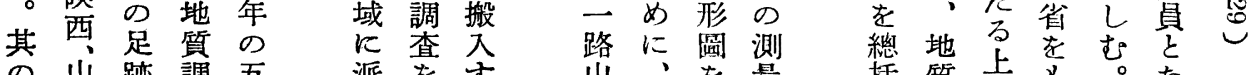

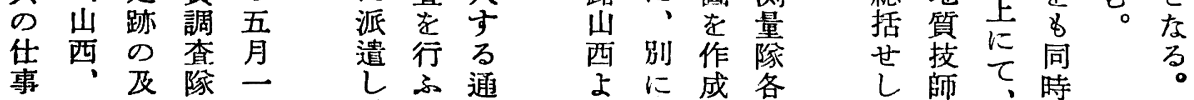



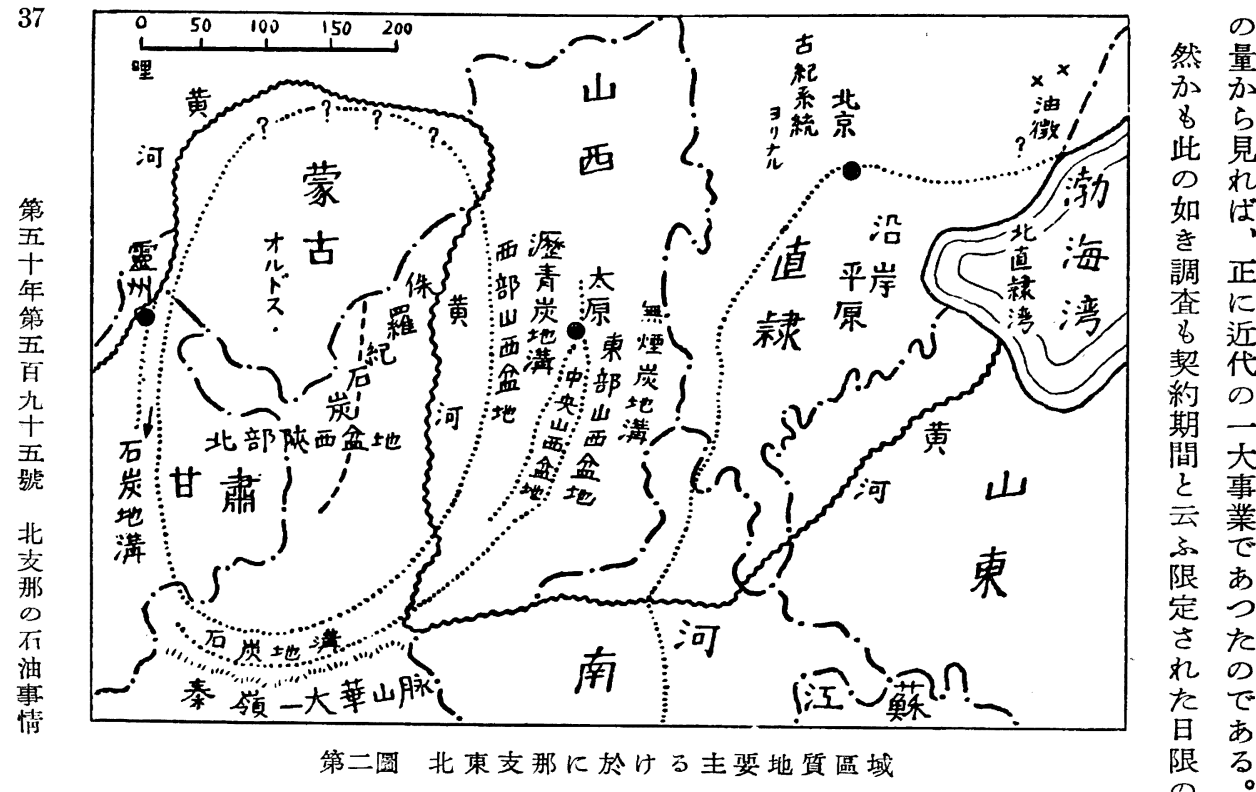

る達河形依る圖上察てラなひけて內

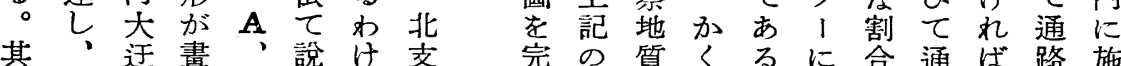
の東曲い北明に那四全の質くるに合通ば路施

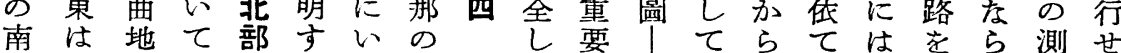
北山附あ陝るか地傸た四脗調、正畫量ね の西近る西こな質西。區論査鯵確きかのば 長省にが盆といに石域、豚察吕落高如店

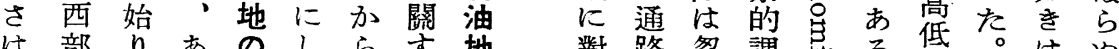
は部り、あのしら、す地對路忽調名る。に售はぬ

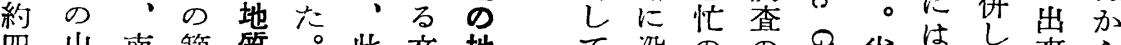

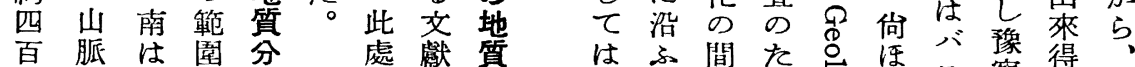

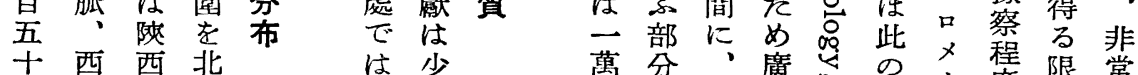
哩 少部第省分之廣心

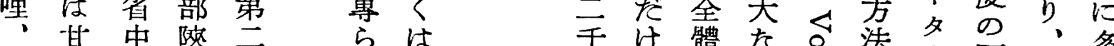
東肅部西胃不古

西省で盆にタい の東 東地北施

幅 部 西と部

はのに云陝

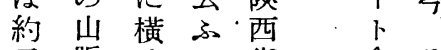

四百を脈は岌省會そ

吾五度居北心 查等

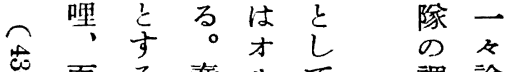

焉面る秦ルて 調論

栍 \& 額ド一查議

にの山ス大報 し

すで脈の楕告て

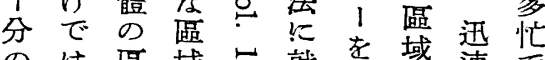

のは區域卢就使に速淢

平あ域を学て俑對であ

板るに旅只は等具つ

测が對行穴本るてつた 量!吉心調方は比こ 地六てる白查法馬較々 形十縮人包に法馬的は 圖七尺々! 從採卡確云 に幅二のに事势步實ふ。 據を十寥詳しし步测なま る完萬考したし測方で

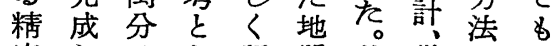
密し,な記質此磁をな な、一方逃學は石採、

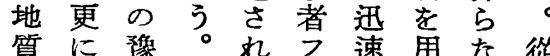




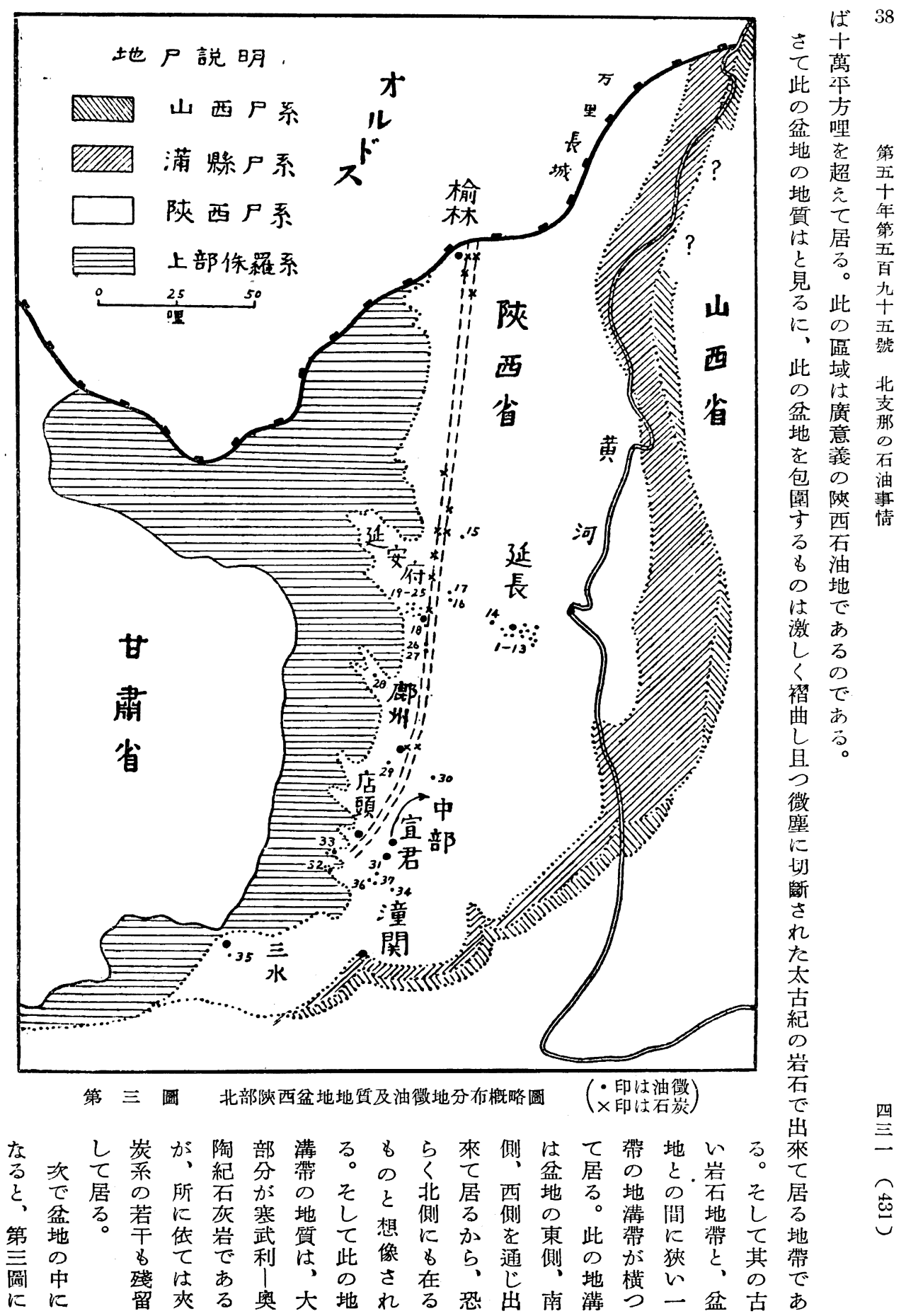


統 南大横云部二畫

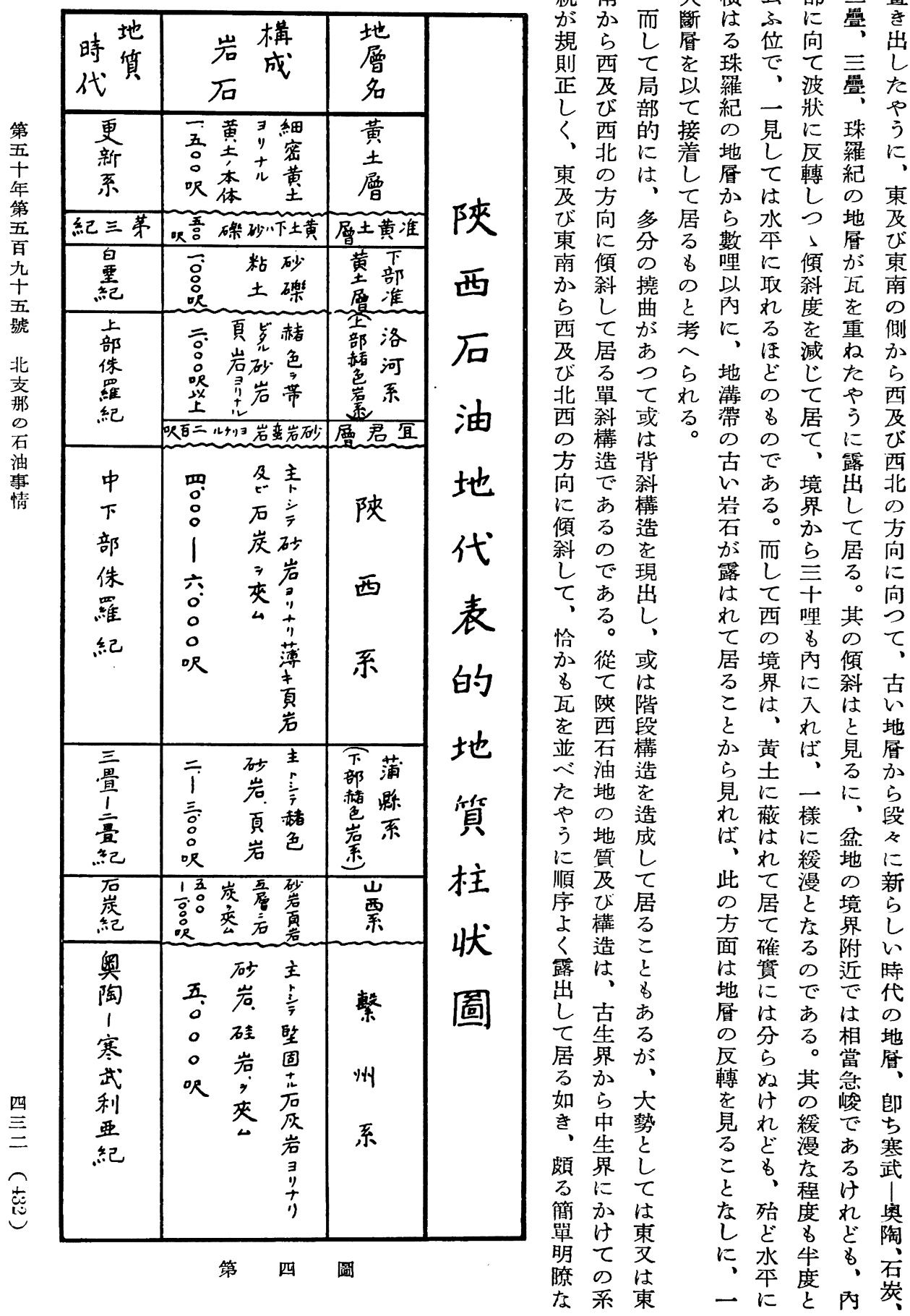




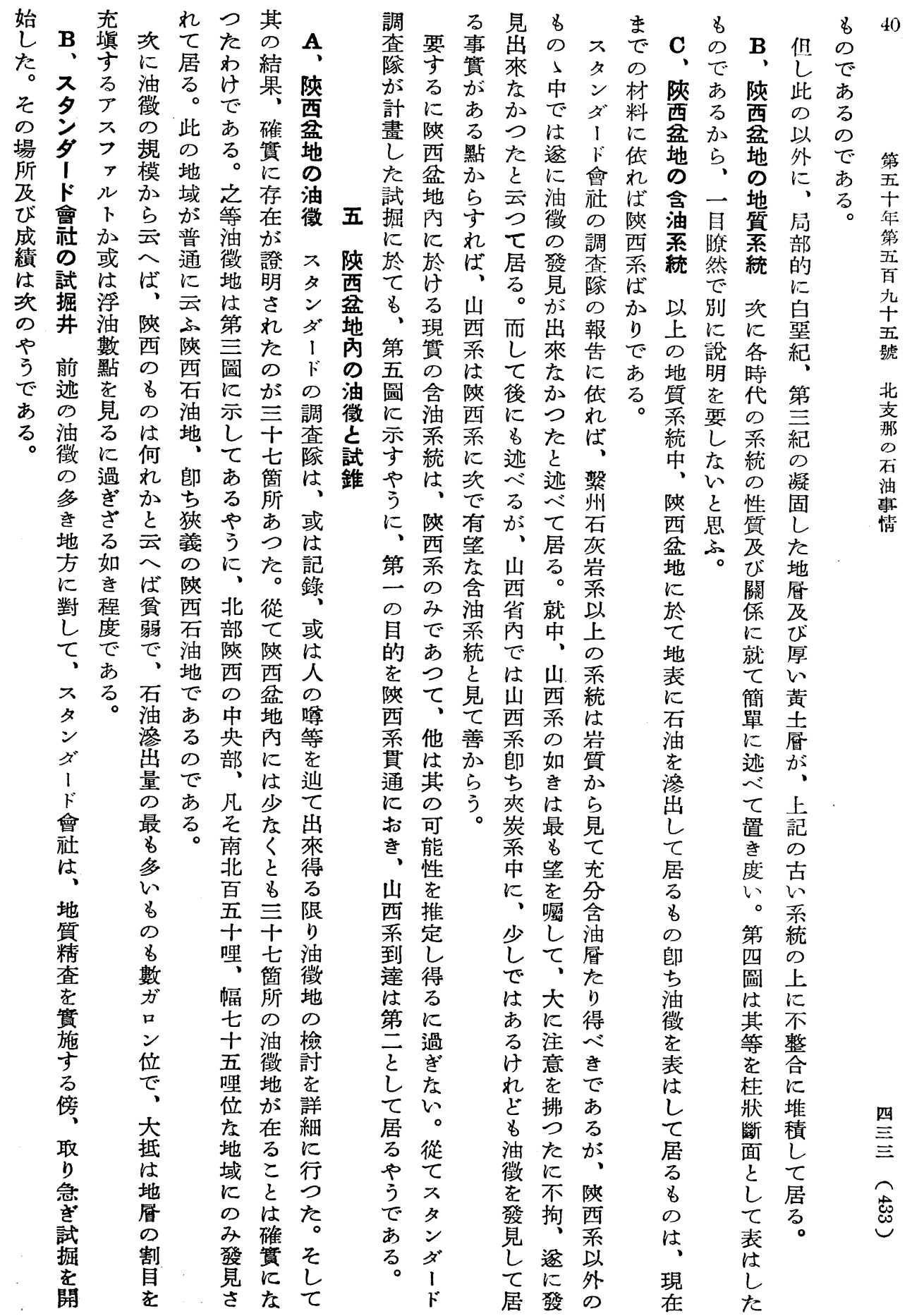




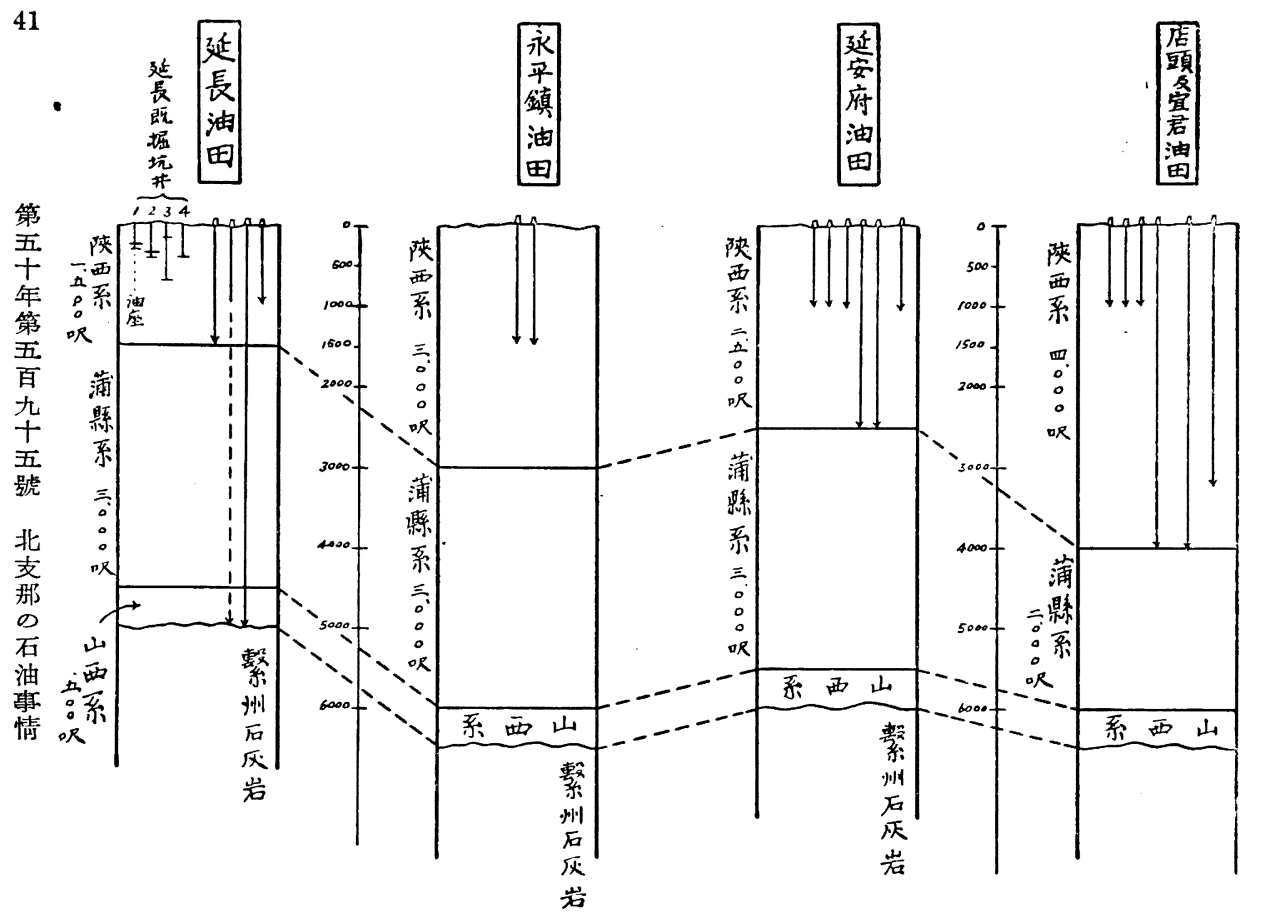

第五圆 傸西油田の地層々 既掘井の油首位及試掘井の目祭

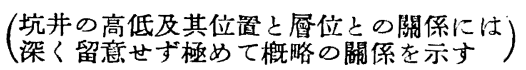

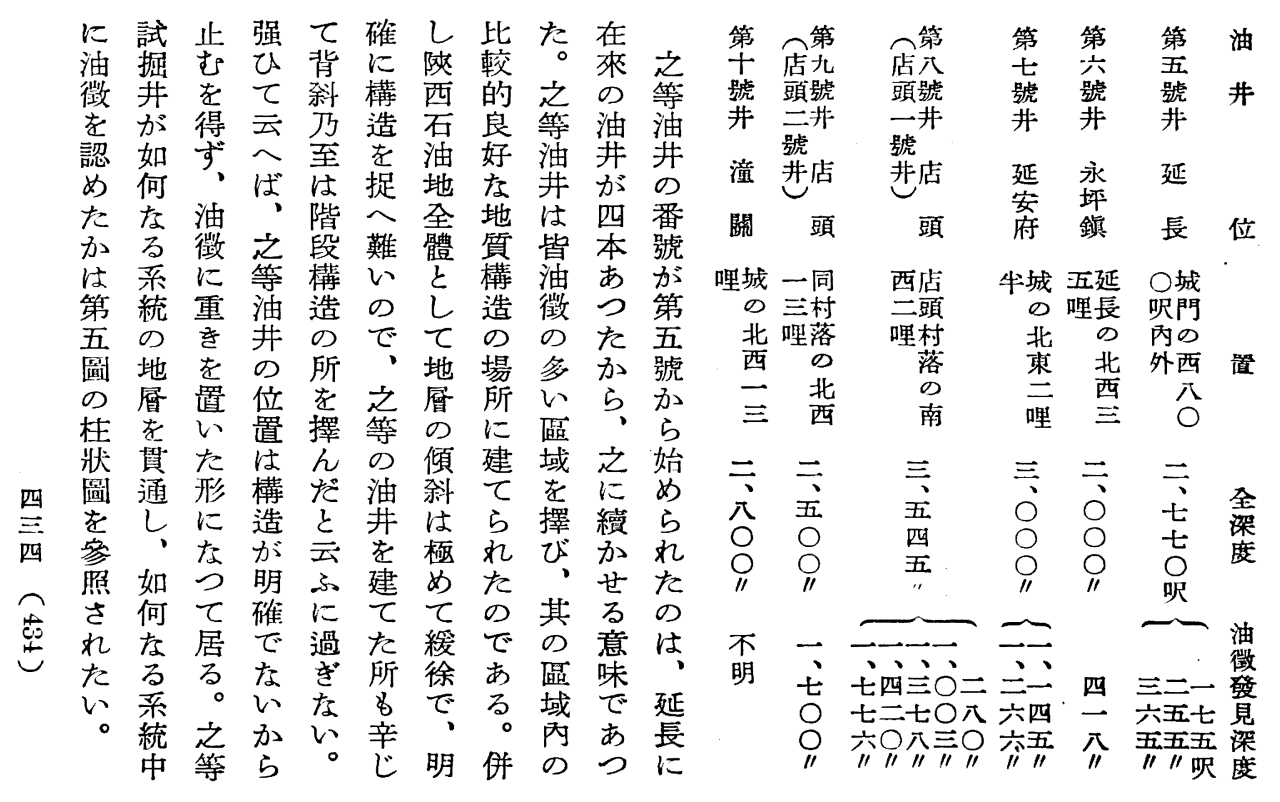




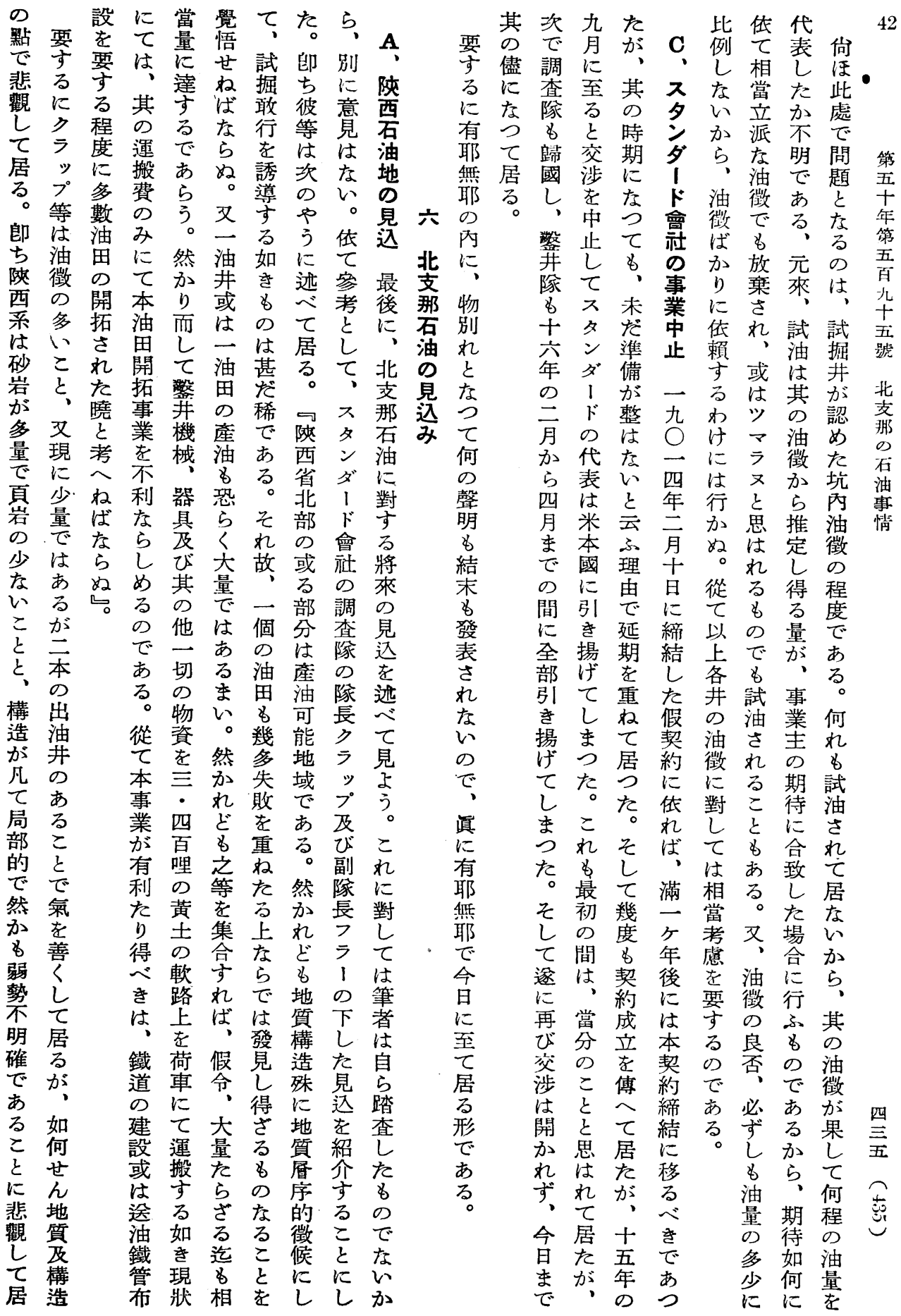




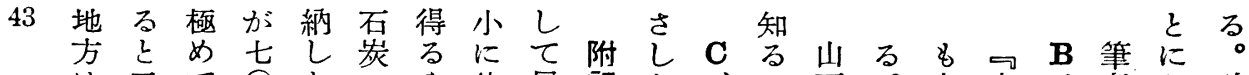
は云てつた市依居記た、西。幸本、著应砂

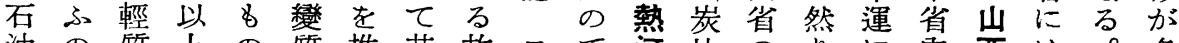
油の質上の質推其故スで河比の然罂西は。多 及でのにでを定の炭名あに說油而しに省别從

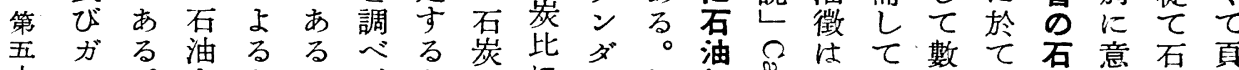

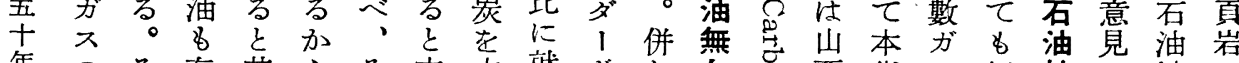

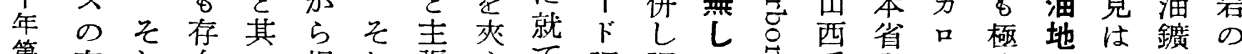

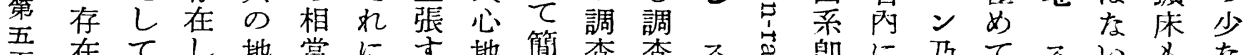

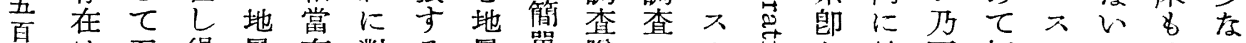

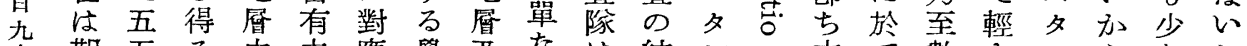

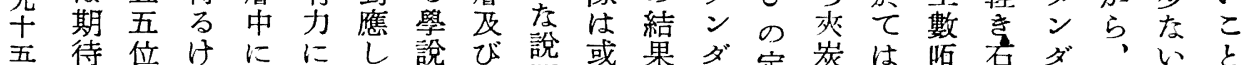

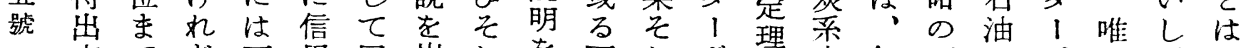

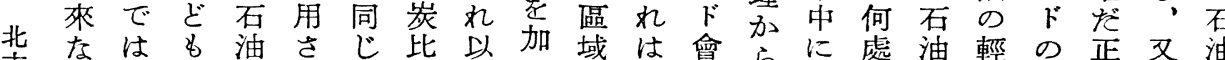

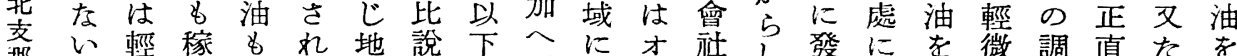

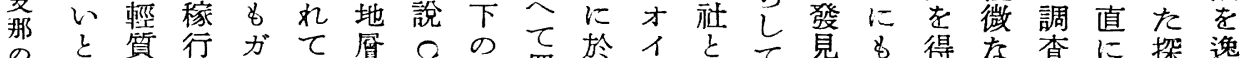

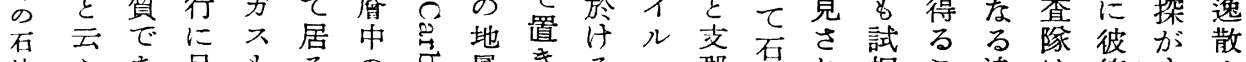

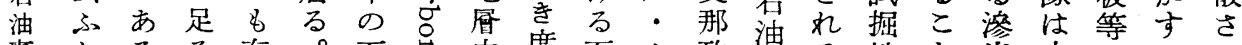
素わるる存。石早中度石七政存る地飞出山のに世

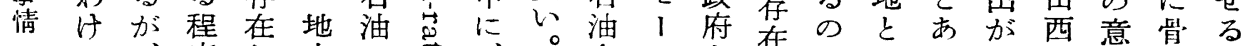
で、度し方の芯!炭有ルと省でしる時省覞が條

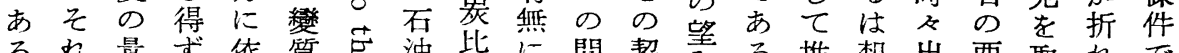
るれ量ず依質㔛油比に間契等る推想出西取れで

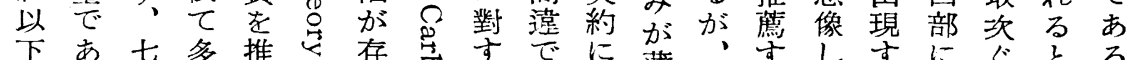

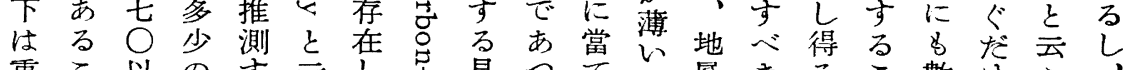

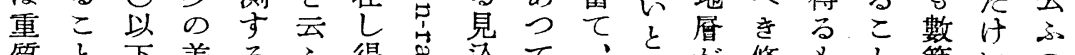

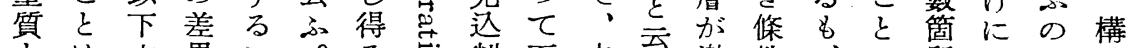
そは六異こ。る宁判石范云激件、は所しで造 な稀五はと此や飞斷油哪こしを稼的のて市の るで位あでの否はのは侧とく具行あ油置る。

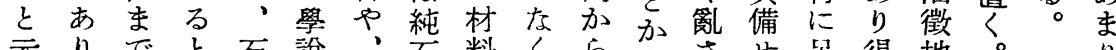

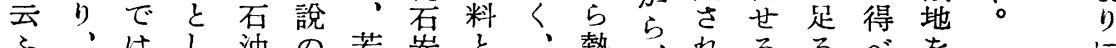

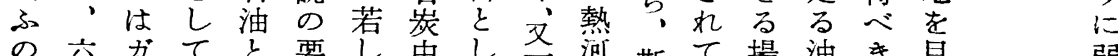
の六ガてと要し中

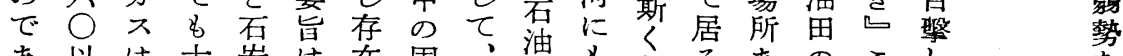
あ以は大炭は在固其のも判るあのこしし な

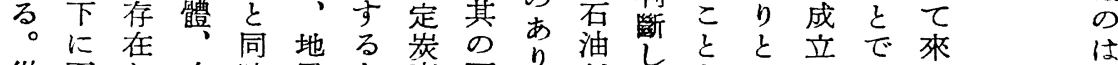

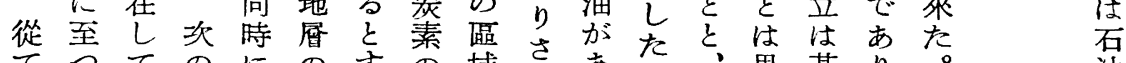

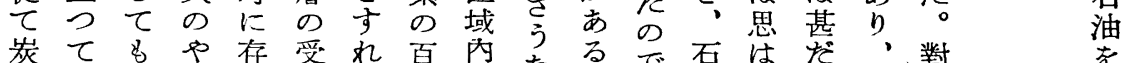

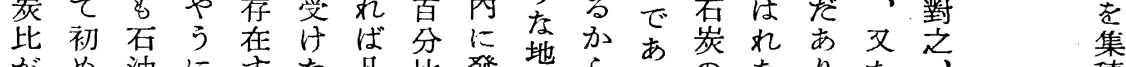

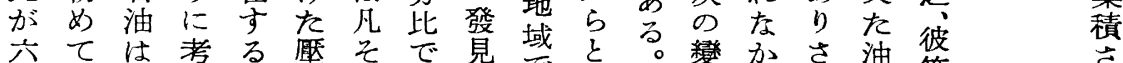

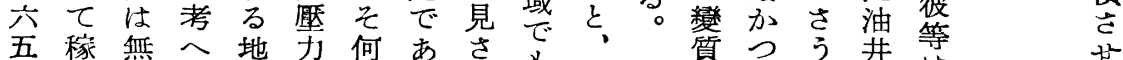

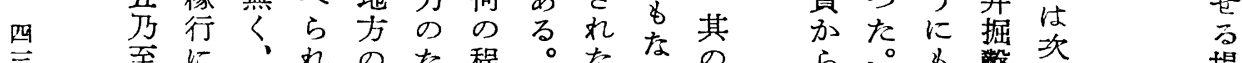

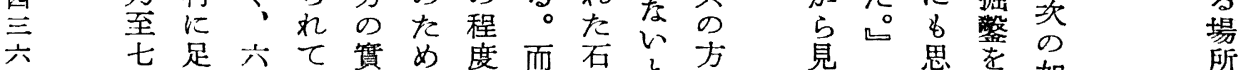

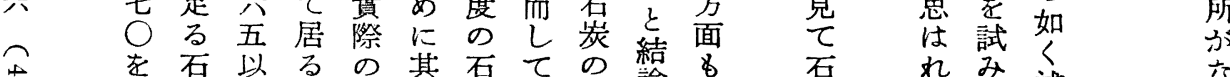

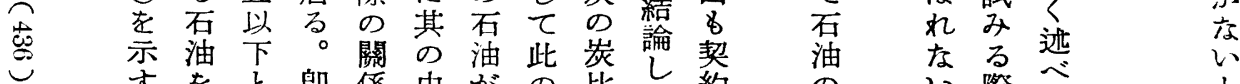

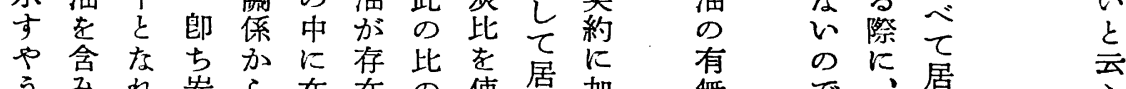

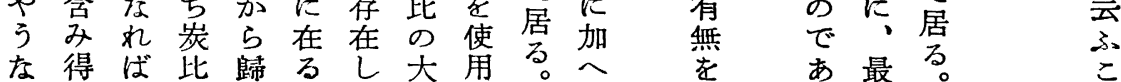




\title{
Oil Resources of North China.
}

\author{
(Abstract) \\ Ichizō Ōmura
}

"Honsō-Kōmoku" published in or about the year 1578 contains a fairly detailed description of all the oil seepages found in the province of Shensi. As this book which treats of medicine has been very popular in Japan and China, knowledge about seepages of Shensi and oil in general seems to have been widely spread about the time of its publication. It is of special interest to note that "Sekiyu" the Japanese word for "petroleum" now in common use is found in this book and it is also very interesting that "Sekiyu" is made of two words "Seki" stone and "yu" oil, having a similar etymological construction as in word "petroleum".

As stated above oil was known in China long ago and its character was fairly well recognized, but as to its industrial utilization, it remained unknown until the beginning of the present century.

Towards the end of the 19th century foreigners who travelled in the interior of China increased and those who saw the actual spots of the seepages in Shensi were highly interested in them and thought of their industrial utilization. This interest in the mind of foreigners was reflected on the Chineses who came to recognize in their turn the value of these seepages.

The first endeavour to exploit these seepages was made by a German capitalist who had applied in 1901 to the men of Shensi province. But as China as a whole did not like to allow exploration of natural resources to foreigners at that time, she declined this application as well as all subsequent ones and decided to work them by the hands of her own people. Under such circumstances the authorities of Shensi province attempted to drill holes themselves, importing the necessary drilling machines drillers from Japan. This Attempt succeeded and the oil was hit at the depth of 230 feet, yielding 60 barrels a day. But the work was soon given up, owing to the lack of money.

But as the result of the revolution of 1912, the Chinese Government and her people suffered a severe financial pressure and was obliged to grant the mining exploration right for loans. And this Shensi oil-field was offered to a Japanese capitalist as a security for the loan, but while this negotiation was going on, the Standard Oil Company (present Socony-Vacuum Oil Company) suddenly made a provisional contract with the Chinese Government, signing in February, 1914. 
Based on this contract, the Standard despatched six geological and five topographical surveying parties which more engaged in survey during the period from May of that year to February next. These parties surveyed Shensi as the centre of their study, but also neighbouring Shansi, Kansu, Honan and even Ordos in order to examine the geological structure of the region throughly. They also surveyed the area now called Nekka province where seepages were said to exist.

Besides the above, the Standard, after the rough survey, attempted the test drillings in Yenchang and other three spots as from December, 1914.

But the Standard did not sign the final contract in March, 1915, as previously arranged and withdrew completely the staffs for survey and exploration in February, 1916.

Though the reason why the Standard has withdrawn is not clearly known, it seems probable that the results obtained by the geological survey were not very promising.

Summary of the part treating "Oil Seepages in Shensi" of "Oil prospects in Northeastern China" by

Myron.L. Fuller and Frederick G. Clapp.

"Summary.….The northern part of Shensi is, within limitations, potential oil territory, but structural and stratigraphic indications that might guide drilling are few, hence pools will be located, if at all, only at the expense of many dry holes. The production of individual wells and pools will probably be small but may be important collectively, although prolific production is unlikely. Since all equipment and supplies must be brought in carts over the 300 to 400 miles of soft loess roads, transportation costs are likely to make operation unprofitable unless a sufficient number of pools are developed to warrant the construction of railways or pipe lines".

In the geology of Shensi oil-field, all the seepages are found in the Shensi system beglonging to the middle or lower jurassic, which is considered to be the main oil bearing stratum. Next to this is the Shansi system of carboniferous age namely coal measure, but in Shensi oil field its existence is at depth very difficult to arrive at. 